\title{
PRESERVATION OF LANGUAGE AND PRINCIPLES OF LOCAL CULTURE BASED MULTICULTURAL EDUCATION IN INDONESIA
}

\author{
Lina Siti Nurwahidah
}

linasitinurwahidah@yahoo.co.id

\begin{abstract}
In the Orde Baru's period, we have been directed to uniformity in many ways. Indonesia, a diverse cultural country was only directed to uniformity that would shape national culture, including Indonesian.Local diversities were just a complement, an addition to the main culture, so it was out of favor and only considered as a secondary culture. Moreover, the early '90s echoes of globalization began to enter into the soul of Indonesian society. Because ofthat, some communities in Indonesia were eroded in sense of nationalism that destabilize the use of Indonesian and glorifies all which came from abroad, including foreign languages. Whereas local culture is very important in the education of multiculturalism, it should be considered in a multicultural-region like ours, Indonesia. The reason is with the locality they can see themselves and also be able to see everyone else.Decentralization of culture including the use of regional languages will not only grow the local culture but also will raise the creativity and resilience of this nation from the onslaught of globalization.
\end{abstract}

Keywords: preservation of language, multicultural education, and local culture

\section{INTRODUCTION}

Indonesia is a diverse country inhabited by people of various ethnic groups. Each ethnic group in Indonesia has a language of their respective regions, which are used in a restricted environment among others.Based on the data published by the Badan Pusat Statistik (BPS) in 2010, Indonesia consists of 1,128 tribal, and ethnographic data noted that there are approximately 700 local languages. The diversity of ethnic groups in Indonesia is caused by historical factors, and natural insulation factor of time. Indonesia's current situation is inhabited by various tribes which have its own characteristics in terms of language and culture, although all of them are included in the same language family of Austronesian languages.

With a wide range of languages and cultures, Indonesia has a rich local knowledge from different ethnic groups there. Local wisdom becomes their views of life which underlie various behavioral patterns and actions of each of Indonesian society. Local wisdom isa kind of response of the phenomenon of globalization, as if it is attempting to homogenize people into cultural patterns. Such conditions can cause the Indonesian people uprooted from their own cultural roots, and become a nation that is losing its identity.Because of that, they who care about the culture of Indonesia, seek to take the wisdoms from their own culture.

Indonesian people should act wisely to participate in a part of the global culture, which is largely dominated by the standards of Western culture. The standard of civilization is measured by the perspective of the West in seeing things, but as a civilized nation, Indonesia also has a strong cultural roots originating from their ancestors, which is no less important and meaningless for the life of the Indonesian people at this time. Those are saved in the heart of 
our culture itself, which in anthropology commonly known as local wisdom or local genius. Local wisdom is also known as local knowledge, or the intelligence of the local, which became the basis of cultural identity.

From days to days, our cultural richesare lost, because there is no new generations who want to preserve it. One indicator that can be seen is from the extinction of several regional languages in Indonesia lately.

\section{PRINCIPLES OF LANGUAGE PRESERVATION AND MULTICULTURALISM}

\section{The Principles Of Language Preservation}

Language preservation is a matter of attitude or assessment of a language to continue to use the language in the midst of other languages. Chaer and Agustina, (1993: 177). Generally, preservation of language aims to maintain a culture that serves as the identity of a group or community, to make it easier to recognize the members of the community, and to engage the sense of brotherhood among the community. This situation generally occurs in communities that have more than one language. The factors that drive it could come from within the individual who has a love for the mother tongue, so they are implanting them to family and community and from the sense of unity and love of the identity of the group or community which is owned.

Factors that affect the shift and the preservation of language are; (a) bilingualismjorkmultilingualism; (b) industrialization; (c) immigration; (d) politics; (e) education; (f.) social mobility; (g) languages' efficiency; (h) number of speakers; (i) the concentration of residents.

Generally, the preservation of language is explained as a decision to continue the use of languages collectively by a community which is using that language before (FAsold: 1984). Moreover, Fasold also stated that the preservation of language is the opposite of language shifting; a community that decided to change their previous language or choosing another language as the replacement of their previous language.

The concept of language preservation is more concerned with the prestige of a language community in the eyes of its supporters. As exemplified by Danie (in Chaer 1995: 193) that the decline in the use of regional languages in East Minahasa is due to the influence of Manado Malay language that has a higher prestige and the use of Indonesian languagethathave a national-range of useage. But there are times when the first language (B1) which hasa fewer number of speakers can withstand the effects of the use of a second language (B2) which is more dominant.

Another concept is more clearly defined by Fishman (in Sumarsono 1993: 1). Language preservation is associated with the changes and the stability of the use of language on one hand with the process of psychological, social, and cultural on the other hand in multilingual societies. One issue that is quite interesting in the study and preservation of language shift is the powerlessness of minority immigrants to maintain their native language in competition with the dominant majority language. The powerlessness of a minority language to survive follows the same pattern. First, the minority grouphadcontacts with a second language (B2), so they knew two languages and become bilingual, then there was a competition in their use of languages, and eventually their native language (B1) became shifted or extinct. 
Commitment is needed in the preservation of a language. It is because of people's development level of science and foreign languages that come into society. It can be seen from the companies which including foreign language as the main requirement to be the employer of those companies. The same problem occurred in the education area. Foreign languages become main courses and also main requirements for graduation. However, in the other side, national and local language has less attention than foreign languages.

\section{Multicultural Principles}

Since its emergence as a discipline in the 1960s and 1970s, Multicultural Based Education (MBE) has been defined in many ways and many different perspectives.

Multiculturalism is the wisdom to see cultural diversity as a fundamental reality in daily life. Wisdom will arise if one opens oneself to live with seeing the reality of plural as a necessity of life, both in life itself which is multidimensional and in community life which is more complex, and therefore a realization that diversity in the reality of the dynamic life is a necessity that cannot be refused, denied, let alone annihilated (Asyari in Mahfud, 2013: 103).

Understanding multiculturalism as a world view is also manifested in the Politics of Recognition. Things like that are also raised by Parekh (Mahfud, 2013: 93), which clearly distinguishes five kinds of multiculturalism, the isolationist multiculturalism, accommodative multiculturalism, autonomous multiculturalism, critical multiculturalism and cosmopolitan multiculturalism. From those types of multiculturalism, we can conclude that multiculturalism is cultural alignment. Each human culture or ethnic group should be positioned at the same level. None is higher and more dominant, because basically all cultures have different traditional wisdoms.

Wisdoms cannot be assessed as positive or negative and cannot be explained through the eyes of another culture. This is caused by the differences in point of view and bad or good root of every culture.

Although multiculturalism that has been used by the founders of this nation to design the Indonesian culture, in general, Indonesian people still perceive their own multiculturalism concept. This concept cannot be equated with the concept of ethnic or cultural diversity which is the characteristic of a plural society, because it emphasizes cultural diversity in equality.

Multicultural education in Indonesia is known as a relatively new approach which is considered more appropriate for the Indonesian who heterogeneous and plural. Moreover, at the time of autonomy and decentralization newly enacted since 1999 until today, multicultural education developed in Indonesia is settled in line with the development of democracy which runs as a counter to the policy of decentralization and regional autonomy. If it is not executed carefully, then it might throwus into national disintegration.

\section{Local CultureUtilization for Language Preservation in a Multicultural Society}

The important role of regional languages have been formulated in explanation of Article 36 UUD 1945 which states, that local languages thatused by its speakers will be respected and maintained well by the state because those languages are parts of Indonesian culture.Moreover, in the Government Regulation No. 25 of 2000 on the government's 
authority and the authority of provinces as autonomous regions mentioned two things that related to Indonesian and local languages.

According to government regulations, it is clearly stated that the promotion and development of Indonesian language and literature is a central authority. However, the activities related to the development of the language and culture of the region belong to the regional authority. Thus, the country that stated in the explanation of Article 36 UUD 1945 is the local government. That is why in the national language policy stated that in connection with the development of national life in Indonesia towards the decentralization of government and the importance of fostering and preservation of local culture, the local language should be given the widest possible opportunity to play a bigger role. National language policy in 1999 underlines the need to give attention to a wider and deeper opportunity for the local language.

The forms of the attention mentioned before are such as developing local language vocabulary. In addition to developing vocabulary or terms fields of science and technology (information), the development should also include the field of culture. The development of that vocabulary can take advantage from the resources of local languages in all areas ofuse of Indonesian. Indonesia has 726 local languages. Doesn't it can be used as a source of enrichment of Indonesian? The utilization of vocabulary is an effort of local culture preservation as well as an attempt to give Indonesian color in developing Indonesian vocabulary. Because of that, it is necessary to study the local language vocabulary. Local languages' vocabularies which have no equivalent in Indonesianshould be incorporated into the vocabulary of Indonesian. If there are differences in pronunciation or the spelling with the Indonesian system, then it necessary to make adjustments to the system of spelling and pronunciation in Indonesian (see Pedoman Umum Pembentukan Istilah). The efforts of involving local languages in the development of Indonesian vocabulary is an attempt to make the Indonesian peoples feel involved in directing the development of their national language, so it will grow their awareness and a sense of belonging to the Indonesian and ultimately increasing their love towards Indonesian.

Thus, the local cultures, including in this case the local language, will continue to exist with all sorts of its knickknacks, because they feel involved. The involvement eventually will be maintained and developed. The existence of Indonesian identity will be kept maintained around regional cultures.

\section{CONCLUSION}

The changing of times will always happen, even more in the era of globalization in this $21 \mathrm{st}$ century. The development and progress in the field of technology and information at such a high rate of speed will certainly directly affect many areas of life. All of it in its turn will give birth to new difficulties and challenges for the sustainability of national's and language's life.

Commitment is needed in the preservation of a language. It is because of people's development level of science and foreign languages that come into society. There will be no problems if they are still solid in defending their basis and put the functions of each of these languages in a responsible manner, but it would be problematic if there are no loyalty of each user to continue to maintain and preserve their languages and cultures. 


\section{REFERENCES}

Alwasilah, A. Chaedar.1993. Pengantar Sosiologi Bahasa.Bandung: Angkasa.

Alwi, H.dan Dendy Sugono (Ed.). 2000. Politik Bahasa. Jakarta: Pusat Bahasa.

Alwi, H., Dendy Sugono, dan A. RozakZaidan. (Ed.). Bahasa Indonesia dalam Era Globalisasi. Jakarta: PusatBahasa.

Anderson, dan Cusher. Multiciltural and Internatural Studies. Sydney: Prentice Hall.

Chaer, Abdul dan Leonie Agustina. 2004. Sosiolinguistik: Perkenalan awal. Edisi Revisi. Jakarta:PT Rineka Cipta.

Crystal,David. 2003.Language Death. NewYork: Cambridge University Press.

Fasold,R.1984.The Sociolinguistics of Society. Cambridge: Cambridge University Press.

Halim, A. 1976. Politik Bahasa Nasional Jilid 1. Jakarta: Pusat Bahasa.

Halim, A. 1976. Politik Bahasa Nasional Jilid 2.Jakarta: Pusat Bahasa.

Hassan, A. (ed.). 1994. Language Planning in Southeast Asia. Kuala Lumpur: Dewan Bahasa dan Pustaka.

Holmes,Janet.1992.An Introduction to Sociolinguistic.New York. Longman.

Mahfud, Ch. 2013. Pendidikan Multikultural.Yogyakarta: PT Pustaka Pelajar.

Moeliono, A. 1985. Pengembangan dan Pembinaan Bahasa: Ancangan Alternatif di dalam Perencanaan Bahasa. Jakarta: Djambatan.

Moeliono, A. 2000. "Kedudukan dan Fungsi Bahasa Indonesia dalam Era Globalisasi" dalam Hasan Alwi, Dendy Sugono, dan A. Rozak Zaidan (ed.). Jakarta: Pusat Bahasa.

Nancy, Hornberger (ed).2006. Language Loyalty, Continuity and Change. Toronto: Multilingual MattersLtd.

Sugono, D. (ed.). 2003. Bahasa Indonesia Menuju Masyarakat Madani. Jakarta: Progress.

Sugono, D. et.al 2003. Setengah Abad Kiprah Kebahasaan dan Kesastraan Indonesia. Jakarta: Pusat Bahasa.

Sugono, D. 2004. "Strategi Perancangan Pengembangan dan Pembinaan Bahasa Indonesia". Makalah Kongres Bahasa Utama Dunia. Kuala Lumpur, 5-8 Oktober 2004.

Sugono, D. 2005. "Dinamika Bahasa dan Sastra Peneral Jiwa Bangsa Serantau" Makalah Seminar Mabbim dan Mastera, Mataram, 7-8 Maret 2005.

Sumarsono.2011.Sosiolinguistik. Yogyakarta:Pustaka.

Sumarsono dan Paina Partana.2002.Sosiolinguistik. Yogyakarta:PenerbitSabda.

Suwito.1983.Pengantar Awal Sosiolinguistik: Teori dan Problema. Edisi ke-2. Surakarta: Fakultas Sastra Universitas Sebelas Maret. 
38 Nurwahidah, Preservation Of Language And Principles Of ... 